\title{
The interdependence between transpiration intensity and the anatomical structure of moss leaves
}

\author{
J. KRUPA
}

Department of Plant Physiology, Higher Pedagogical School Cracow

(Received: April 6, 1976)

\begin{abstract}
The degree of anatomical differentiation of moss leaves, as well as differing biotropic conditions of these plants, served as a basis for the choice of the following species: Mnium punctatum, Catharinea undulata, Funaria hygrometrica, Polytrichum juniperinum, Polytrichum piliferum, and Aloina rigida. Different anatomical structure of severed moss leaves does not generally influence the quantity of water evaporated during a 24-hour period, while they are kept in an atmosphere of relative humidity of $85 \%$ and $95^{\circ} \%$. The differences observed in the dynamics of water loss from leaves under conditions of relative atmospheric humidity of $85 \%$ are more likely due to the properties and structure of cell walls, though they may also, result from different resistance of cytoplasm to evaporation. The process of photosynthesis exhibits a significantly greater sensitivity to variations in water content of leaf than does the process of respiration. In most of the studied species, the respiration activity decreases. markedly, though it does not become completely arrested following the period of dehydration applied.
\end{abstract}

\section{INTRODUCTION}

In nature, mosses occupy extremely differing habitats with respect to water supply. They develop and mature in water as well as in extremely dry places, such as bare rock, or sandy areas. The possibility of development under such extreme conditions is related to these plants' remarkable resistance to dehydration, which makes them similar in this respect to lichens (S t a $1 \mathrm{f}$ et 1960; L a n g e et al. 1970; Lange and Evenari 1971).

Mosses and lichens can endure long periods of draught in a state of dehydration, and their physiological processes become reactivated after rehydration (Tallis 1959; Hinshiri and Proctor 1971; 
Lee and Stewart 1971). Only hours, or even minutes, following rehydration, respiration and photosynthesis become reactivated. The period of time necessary to reactivate physiological processes differs widely and depends on many factors. The process of dehydration and rehydration may be repeated several times without lethal effects to the entire plant.

These plants significant resistance to dehydration and the lack of mechanisms protecting them from excessive water loss, leads one to presume the existence of physiological capabilities for adaptation to changeable water content of cells. The decrease of water content in moss leaves of about $10 \%$ below their full capacity results in a decrease of photosynthesis intensity of more than $50 \%$ of initial value ( $\mathrm{Plan}$ tefol 1927; Engsreber 1954; T a 11 is 1959). An excessive decrease in water content results in an arrest of metabolic acivity, or in its remarkable limiting, for the duration of drought.

As has been shown by Bew ley (1973) in a study carried out on leaves of Tortulla ruralis, mosses, during dehydration, "preserve" their polyribosomes in an undamaged condition, which enables them to restore rapidly protein synthesis following rehydration. This ability may be considered as an ecological adaptation property, all the more so, since in other plants, irreversible disintegration of protein-synthesizing apparatus occurs during dehydration. It is undoubtedly one of the properties which enable mosses to endure even prolonged periods of drought.

The anatomical structure of moss leaves is rather primitive, and in most species the leaf blade is generally composed of a single layer of cells. In spite of their primitive structure, moss leaves exhibit certain differences in morphology, as well as in their anatomical structure. These differences concern quantitative relationships and the occurrence of various anatomical structures. For example, the leaf blade of Mnium or Funaria is, in principle, composed of a single layer. Mosses belonging to Polytrichaceae, have lamellae on the top surface of the blade, which are built of a number of cells distributed along the leaf's veins. The presence of anatomical structures on the leaf surface is related to the size of the assimilation surface and of the leaf itself.

On the basis of the above, one may speculate as to whether the observed structural variations of moss leaves are an expression of certain evolutionary trends in this organ, and whether these tendencies are related to the adaptation to the conditions of life on land. However, the lack in leaves of clearly functionally determined anatomical structures which would protect that organ from excessive water loss, makes the metabolic activity of mosses dependent on water conditions in their environment.

As it has been mentioned, moss leaves subjected to conditions of 
deprivation of water in liquid form, become dehydrated rapidly. Differences in the area of evaporation surface and the presence of certain anatomical structures may result in differences in the rate and quantity of water loss by the leaves. Changes in the amount of water contained by the leaves will significantly influence the intensity of gas exchange. It was for these reasons that evaporation intensity was determined from the leaves of 6 moss species, differing with respect to anatomical structure as well as to habitat, and the intensity of respiration and photosynthesis was designated for leaves partly deprived of their normal water content.

\section{MATERIAL AND METHODOLOGY}

In the experiments, the leaves of six moss species were used: Mnium punctatum, Funaria hygrometrica, Catharinea undulata, Polytrichum juniperinum, Polytrichum piliferum, and Aloina rigida. The choice of the moss species used in experiments was based on the anatomical structure of leaves and the habitat of each species (see results).

Gametophores collected in natural habitat were grown in a light thermostat. The particular species were grown in glass trays and covered with transluscent glass plates. The plants were illuminated using 12 hour day and night periods. As light sources, LFRF type, 250 Watt lamps (produced by Polam), and 4 incandescent bulbs of 200 Watt intensity each, were used. Infra-red radiation was eliminated by the use of "antysol" glass cooled by air. The intensity of light reaching each tray was regulated to match the average intensity observed in the natural habitat of each species during summer months. A decrease in light intensity was obtained by covering the trays with neutral filters made of blackened copper mesh. During the light phase, the temperature inside the thermostat was $20^{\circ} \mathrm{C}$. In order to obtain effects such as dew, the temperature was lowered to about $10^{\circ} \mathrm{C}$ during the dark phase.

The intensity of gas exchange was measured with the aid of microrespirometric method (Zurzycki 1970; Krupa 1969). Respiration intensity was measured in darkness. Photosynthesis intensity was determined in the light coming from wolfram lightbulb (Tugsram $1000 \mathrm{~W}$ ), within the range of optimum intensities for each moss species (Krupa 1977).

In order to remove a certain amount of water from the leaves, they were placed over a solution of carbonate buffer of 3 mol. concentration. After a certain period of time, the mass of leaves kept under these conditions does not change any further, which would signify a stabilization of water content at a stable level. The period required for reaching 
the stability has been determined for each species and designated experimentally.

The intensity of gas exchange in previously partially dehydrated leaves was measured with the use of carbonate buffer of $3 \mathrm{~mol}$ concentration. Such concentration of the buffer ensures a $0.3 \%$ concentration of gaseous $\mathrm{CO}_{2}$ and maintains a relative atmospheric humidity of $85 \%$. During the measurement, the leaves were attached to glass plates covering the chambers, by a very small amount of pure vaseline. In all experiments, leaves coming from the same area of the stem were used. The leaves of $P$. juniperinum, $P$. piliferum, $C$. undulata, and $F$. hygrometrica were taken from spots about $0.8 \mathrm{~cm}$ below the summit of the stem. In experiments with the leaves of $A$. rigida and $M$. punctatum, on the other hand, well formed mature leaves were utilized. Dry and fresh mass was determined with the aid of suitably adapted micro-balance (Z urzycki and Dyakowska 1959).

The rate of evaporation and the quantity of water evaporated from the leaves was determined in the atmosphere of relative humidity of $85 \%$ and $95 \%$. For that purpose, the leaves were placed in scale trays over a 3 mol. carbonate buffer of the following composition: 40 parts $\mathrm{KHCO}_{3}$ and 60 parts $\mathrm{K}_{2} \mathrm{CO}_{3}$, which has also been used in the measurement of gas exchange ( $\mathrm{Z} \mathrm{urzycki} 1970$ ).

After detaching the leaves from stems, water was removed from the leaf surface with the aid of a blotting paper and the leaves were quickly weighed. After determining their fresh mass, the leaves were immediately removed to scale trays containing carbonate buffer, and following the proper period of time they were weighed again and then dehydrated for 24 hours in the temperature of $105^{\circ} \mathrm{C}$. A similar procedure and conditions were maintained during the determination of the amount of water evaporated over a $\mathrm{NaCl}$ solution of 1 mol concentration, which maintained the relative atmospheric humidity at $95 \%$.

\section{RESUTS}

The moss species used in experiments are characterized by different anatomical leaf structure, or they occur in different habitats.

The leaves of Mnium and Funaria (Fig. 1) consist of a single layer of cells, and their top surface is smooth. Differences in the structure of leaves of Mnium and Funaria concern, among others, the thickness and surface of the leaf blade. The leaves of Catharinea undulata, on the other hand, have on the underside of the leaf blade $4-6$ rows of lamellae running along the vein (Fig. 1c). A further increase in the amount of lamellae may be observed in the leaves of Polytrichum juniperinum. Nearly entire top part of the leaf blade is covered closely by 

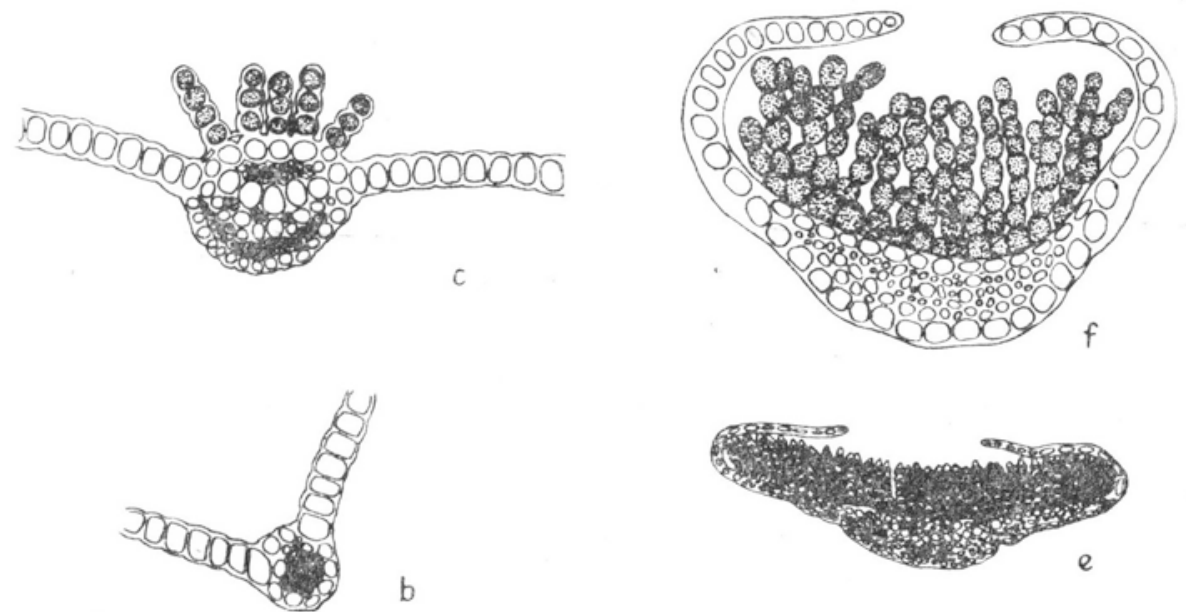

b
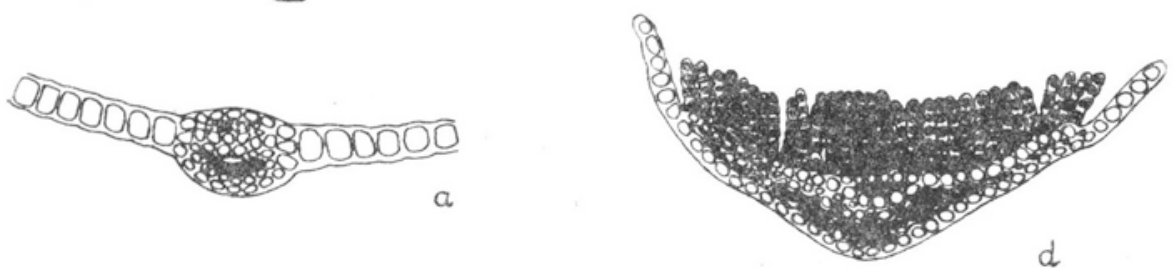

Fig. 1. An outline of anatomical structure of leaves of the mosses: a-Mnium punctatum, b-Funaria hygrometrica, c-Catharinea undulata, $d$-Polytrichum juniperinum, e-Polytrichum piliferum, and f-Aloina rigida

slats. These slats run along the leaf's length, and their number varies according to the width of the leaf blade. The top cells of the lamellae are often structured differently from other cells.

A dehydrated leaf becomes misshapen in such a way, that lamellae are covered by the leaf edge. The leaves of Polytrichum piliferum (Fig. 1e) are characterized by anatomical structure similar to the one described above. The edge of the leaf is curled up in such a way, that it covers a large proportion of the lamellae. The top cells of the lamellae have particularly thick cell walls, additionally covered with papillae. The average area of the leaf contour is remarkably smaller than in previously mentioned species.

The leaves of Aloina rigida have a different anatomical structure. The vein, rather broad and flat, is covered along the entire length with thin assimilation filaments. These filaments are often branched out and contain large amounts of chloroplasts. End cells of the filaments are thick-walled, particularly in their upper parts. The vein, along with the filaments, is partly protected (in the state of saturation of the leaf) by curled-up edges of the leaf. Following a partial water loss, the leaves are deformed in such a way, that the vein is fully exposed. The 
edge of the leaf, yellowish green in color, is made up of a single layer, and the cells contain small amounts of chloroplasts. The leaf is stiff, ligulate-lancetlike in shape. In dehydrated state, leaves adhere to the stem, and the entire plant assumes the shape of a closed rosette. The dimensions of the leaf are rather small, the average area being $0.0038 \mathrm{~cm}^{2}$.

With respect to, among others, the light conditions prevalent in their natural habitat, Funaria hygrometrica, Polytrichum piliferum, and Aloina rigida may be included among photophilics. The other species, as: Mnium punctatum, Catharinea undulata, and Polytrichum juniperinum, belong to shade-seeking plants (see also $\mathrm{Krupa} \mathrm{1977).}$

\section{Evaporation of water from leaves}

Placing the moss leaves in an atmosphere of relative humidity of $85 \%$ leads to their rapid loss of water. Evaporation intensity, calculated as a percentage of total amount of water contained in fully saturated leaves, shows a differentiation in the dynamics of this process in different moss species (Table 1). Following about $0.5 \mathrm{hr}$. since the initial measurement, the leaves of Aloina evaporate nearly $79 \%$ of their tota? water content, while during the following hour in the same conditions the amount of water evaporated increases only insignificantly. Finally, after 24 hours, $90.4 \%$ of total water content of the leaf becomes evaporated, and the water content calculated as a percentage of the leaves' mass* amounts to 16.1. Aloina leaves, remaining for 24 hours in an atmosphere of higher relative humidity of $95^{\%} \%$ also evaporate significant quantities of water contained within them. The percentage of total evaporated water is 84.1 following that period, and the water content as a percentage of the leaf mass falls down to 31.7 . The amount of water evaporated following the same period of time but in different atmospheric conditions is similar in this species, and the difference expressed as a percentage of total water loss is 6 . However, the water content calculated as a percentage of the mass of leaves kept for 24 hours under different humidity conditions shows marked differences. The amount of water remaining in leaves kept over a sodium chloride solution is nearly twice as high as it is in leaves placed in the atmosphere of $85 \%$ humidity.

The leaves of $P$. piliferum are characterized by significantly lower water loss dynamics, since after $0.5 \mathrm{hr}$. in the atmosphere of $85 \% \mathrm{hu}-$ midity they lose only $50 \%$ of their total water content. After $24 \mathrm{hrs}$ in these conditions, the amount of water lost is $82.2 \%$, and the water con-

* The percentage of the leaves' mass denotes their water content calculated as a percentage of the mass of leaves following a 24-hour period of keeping those leaves under definite conditions of relative atmospheric humidity. 
tent of leaves is on a level similar to that of the species discussed previously.

On the other hand, leaves of $P$. piliferum kept in the atmosphere of $95 \%$ humidity evaporate about half of their water content after 24 hour period.

The leaves of $P$. juniperinum contain on average $61 \%$ of water expressed as a percentage of fresh mass. After keeping them for $30 \mathrm{~min}$ utes in an atmosphere of $85 \%$ relative humidity, nearly $73 \%$ of their total water content is evaporated. In the end, i.e. after a 24-hour period, leaves of this species lose $92.4 \%$ of their total water content in the state of full saturation. The water content, on the other hand, calculated as a percentage of the leaves' mass after keeping them for 24 hours in an atmosphere of $85 \%$ humidity amounts to 10.7 and is nearly 4 times lower than in leaves kept under conditions of $95 \%$ relative humidity. After keeping the leaves for 24 hours in an atmosphere of $95 \%$ humidity, around $60 \%$ of total water content is evaporated. A similar course of evaporation is observed in the leaves of $C$. undulata, while the leaves of $F$. hygrometrica contain the lowest amount of water after being kept for 24 hours over a 3 mol. solution of carbonate buffer, and that amount is nearly 4 times lower than the water content of leaves kept for the same period of time in an atmosphere of $95 \%$ humidity (Table 1). Much more resistant to water loss (at least during the initial 30 minutes) ore the leaves of Mnium. Leaves of this species, placed in an atmosphere of $85 \%$ humidity, lose only about half of their water during the first 30 minutes. After a longer period in the same conditions, the amount of water evaporated increases, and after 24 hours $84.2 \%$ of total water content is evaporated. When the leaves are kept in an atmosphere of $95 \%$ humidity, only $44.5 \%$ of their water is evaporated, and their water content calculated as a percentage of leaf mass is 55.5. The existence of thick cell walls and their specific properties may explain the fact that leaves of this species show a course of the evaporation process similar to that of the $P$. piliferum leaves.

It is characteristic that nearly all of the investigated moss species, whose leaves were placed in an atmosphere of humidity lower than saturation, are subject to a rapid and significat loss of water. Such rapid water loss in such quantities will influence to a large degree the metabolic activity of these plants, and in particular the processes of photosynthesis and respiration.

\section{Gas exchange in partly dehydrated leaves}

The measurements made of the intensity of gas exchange of partially dehydrated leaves point to a remarkable drop in the intensity of photosynthesis and respiration. The intensity of net photosynthesis de- 
The course of water evaporation from moss leaves in different

\begin{tabular}{|c|c|c|c|c|c|}
\hline Moss species & $\begin{array}{c}\text { Water } \\
\text { content } \\
\text { as } \% \text { of } \\
\text { fresh mass } \\
\text { of leaves }\end{array}$ & $\begin{array}{l}\text { Water content } \\
\text { as \% of mass } \\
\text { of leaves after } \\
24 \text { hrs in atmo- } \\
\text { sphere of } \\
\text { Rh } 95 \%\end{array}$ & $\begin{array}{l}\text { Water content, } \\
\text { as } \% \text { of mass } \\
\text { of leaves after } \\
24 \text { hrs in atmo- } \\
\text { sphere of } \\
\text { Rh } 85 \%\end{array}$ & $\begin{array}{c}\text { Amount of wa- } \\
\text { ter evaporated, } \\
\text { as } \% \text { of total } \\
\text { water content, } \\
\text { after } 24 \text { hrs in } \\
\text { atmosphere of } \\
\text { Rh } 95 \%\end{array}$ & $\begin{array}{l}\text { Amount of water } \\
\text { evaporated as } \\
\% \text { of total water } \\
\text { content, after } \\
24 \text { hrs in atmo- } \\
\text { sphere of } \\
\text { Rh } 85 \%\end{array}$ \\
\hline Aloina rigida & 69.5 & 31.7 & 16.1 & 84.1 & 90.4 \\
\hline $\begin{array}{l}\text { Polytrichum } \\
\text { piliferum }\end{array}$ & 56.5 & 38.0 & 16.9 & 49.3 & 82.2 \\
\hline $\begin{array}{l}\text { Polytrichum } \\
\text { juniperinum }\end{array}$ & 61.0 & 38.0 & 10.7 & 60.3 & 92.4 \\
\hline $\begin{array}{l}\text { Catharinea } \\
\text { undulata }\end{array}$ & 64.1 & 32.9 & 20.5 & 68.2 & 85.5 \\
\hline $\begin{array}{l}\text { Funaria } \\
\text { hygrometrica }\end{array}$ & 80.3 & 47.0 & 8.8 & 81.7 & 93.0 \\
\hline $\begin{array}{l}\text { Mnium } \\
\text { punctatum }\end{array}$ & 65.6 & 55.5 & 26.4 & 44.5 & 84.2 \\
\hline
\end{tabular}

termined in the leaves after stabilization of their water content at a stable level, reaches negative values. The marked dehydration of moss leaves used in the experiments results in total arrest of the process of photosynthesis, and the intensity of actual photosynthesis is practically equal to zero (Table 1). Respiration, on the other hand, shows a differentiation in the sensitivity to the decrease in water content in the leaves of different moss species. A drop in the water content of Funaria hygrometrica leaves results initially in a rise in the intensity of respiration, whereby it is $15 \%$ higher than in fresh, fully saturated leaves. In leaves of the remaining species, a drop in the intensity of respiration may be observed when compared to the intensity of that process in fresh leaves. The drop is correlated to some extent with the area of leaf surface and with its anatomical structure (Fig. 1). In dehydrated Mnium punctatum leaves there occurs a 35\% drop in the intensity of transpiration, which is significantly less than in other species, which have leaves of non-single layer structure. However, the significant dehydration of leaves in all species does not in the end result in a total arrest of gas exchange - which is one more proof of strong and differentiated adaptation abilities of such hydrolabile plants as mosses. 
ble 1

relative atmospheric humidity $(\mathrm{Rh})$ and the intensity of gas exchange

\begin{tabular}{|c|c|c|c|c|c|c|c|c|c|}
\hline \multirow{2}{*}{\multicolumn{5}{|c|}{$\begin{array}{l}\text { Amount of water evaporated from } \\
\text { leaves as } \% \text { of total water content, } \\
\text { in atmosphere of } \mathrm{Rh} 85 \% \text {, after } \\
\text { different periods of time, in hours }\end{array}$}} & \multirow{3}{*}{$\begin{array}{c}\text { Intensity of } \\
\text { transpiration } \\
\text { of dehydrated } \\
\text { leaves as } \% \text { of } \\
\text { the intensity } \\
\text { in fresh leaves }\end{array}$} & \multicolumn{4}{|c|}{$\begin{array}{c}\text { Intensity of gas exchange, } \\
\text { in } \mu \mathrm{l} \mathrm{O}_{2} \cdot 100^{-1} / 10 \mathrm{~min} . / 1 \mathrm{mg} \text { dry mass } \\
\text { of fresh and dehydrated leaves }\end{array}$} \\
\hline & & & & & & \multicolumn{2}{|c|}{ respiration } & \multicolumn{2}{|c|}{$\begin{array}{c}\text { net } \\
\text { photosynthesis }\end{array}$} \\
\hline 0,5 & 1 & 1,5 & 2 & 2,5 & & fresh & dry & fresh & dry \\
\hline 78.9 & 84.5 & 87.9 & 86.2 & & 20.8 & 4.22 & 0.88 & +17.7 & -0.85 \\
\hline 46.2 & 64.6 & 73.9 & 76.0 & 77.2 & 20.7 & 2.32 & 0.48 & +5.69 & -0.60 \\
\hline 72.8 & 80.2 & 81.4 & 80.7 & - & 29.7 & 2.12 & 0.63 & +11.2 & -0.90 \\
\hline 67.3 & 81.2 & 82.3 & 83.4 & - & 35.9 & 3.56 & 1.28 & +11.4 & -1.40 \\
\hline 71.2 & 86.3 & 87.9 & - & - & 115.7 & 2.80 & 3.24 & +16.4 & -3.78 \\
\hline 43.1 & 70.3 & 79.5 & 84.0 & - & 65.0 & 1.86 & 1.21 & +12.1 & -1.52 \\
\hline
\end{tabular}

\section{DISCUSSION}

The process of water evaporation from moss leaves in an atmosphere of less than saturation humidity occurs rather rapidly, and, in principle, is independent of the anatomical structure of that organ. On the other hand, the water content calculated in relation to the leaves' mass after a 24-hour period of dehydration, as well as the amount of water evaporated varies with the relative atmospheric humidity. Already after 30 minutes of dehydration, the leaves of investigated moss species lose remarkable amounts of water, relative to their total water content, and attain in principle a state of equilibrium after about 2 hours.

The extending of dehydration period to 24 hours does not cause essential changes in the water content. However, the final amount of water contained in the leaves of particular species shows a differentiation characterized by the highest value for leaves of Mnium, kept in an atmosphere of $85^{\%} \%$ relative humidity, and for Mnium and Funaria in an atmosphere of $95 \%$ humidity. Such course of evaporation in the leaves of particular species, related to the varying properties of cell walls (thickness and content) as well as the uneven loss of water for particular cell element, is reflected in the intensity of gas exchange. Measurements taken of the intensity of photosynthesis and respiration during the period following stabilization of the water content at a constant level ( $1-2$ hours of dehydration) showed a high sensitivity of 
the process of photosynthesis to changes in water content of the leaf. The process becomes arrested in leaves of all moss species.

Simultaneous measurements of respiration intensity in the dark show that the intensity of that process in the leaves of Funaria is higher under these conditions than it is in fresh, fully saturated leaves. A much smaller drop in respiration intensity was observed in Mnium $(35 \%)$ than in the remaining species. The above results confirm the observations of other authors (Stalfelt 1937; Plantefol 1927; Ensgreber 1954) which spoke of the process of photosynthesis being more sensitive to changes in the water content of moss leaves, than the process of respiration.

Following rehydration, dehydrated moss leaves show a reactivation of the processes of photosynthesis and respiration. The degree of reactivation of photosynthesis depends on the quantity of water previously lost, the period of dehydration, as well as resistance to dehydration related to properties of the cytoplasm (I r m s cher 1912; B i e b l 1964). In many moss species, respiration intensity increases with time elapsed since their rehydration, and finally reaches a value close to the original intensity of that process prior to dehydration ( $\mathrm{T}$ a 11 is 1954; Hinshiri and Proctor 1971; Lee and Stewart 1971).

The increase in respiration intensity and the rapid reactivation of that process following the increase of water content of the cell is an attribute of plants of arid areas. (Stiles 1960). However, the reactivation of metabolic processes in general, and of the respiration process in particular, following a period of severe dehydration is related, in mosses from arid areas, to the possibility of preserving the ability for and the rapid return of the processes of synthesis of new proteins (B ow ley 1972, 1973). The ability to synthesize proteins after dehydration of leaves is related to the preservation of undamaged polyribosomes. Since during the initial period after dehydration, no increase in the amount of RNA is observed, the change in the protein level in the cell should be attributed to the activities of previously existing ribosomes, which are preserved undamaged during the period of drought. This ability has been observed in mosses growing in arid areas. Such property has not been observed, however, in vascular plants or in aquatic mosses. In those organisms, an irreversible disintegration of protein-synthesizing system occurs after major dehydration. The ability to preserve undamaged polyribosomes during dehydration may be recognized as one of the aspects of the adaptational possibilities of mosses.

The differentiation of anatomical structure of leaves, observed within this group of plants, does not constitute sufficient safeguard against water loss. In the leaves of vascular land plants, the limiting of transpiration is related to the separation of the inner evaporation 
surface from the atmosphere by an outer skin, which surrounds the structurally developed assimilative tissue. In mosses, there is a tendency for a gradual differentiation in the anatomical structure of leaves, which, under favourable water conditions, leads to an increase in photosynthetic production of the leaves.

\section{REFERENCES}

B ewley J. D., 1973. Polyribosomes conserved during desication of the moss Tortula ruralis are active, Plant Physiol. 51: 285-288.

Bi ebl R., 1964, Austrocknungsresistenz tropischer Urwaldmoose aus Puerto Rico, Protoplasma 59: 278-297.

Ensgraber A., 1954, Uber den Einfluss der Antrocknung auf die Assimilation and Atmung von Moosen und Flechten, Flora 141: 432-475.

Hinshiri H. M., Proctor M. F., 1971, The effect of disiccation on subsequent assimilation and respiration of the bryophytes. Anomodon viticulosus and Porella platyphylla, New Phytol, 70: 527-538.

Irmscher E. 1912, Utber die Resistenz der Laubmoose gegen Austrocknung und Kälte, Jb. Wiss. Bot. 50: 387-400.

Krupa J., 1969, Photosynthetic activity and productivity of the sporophyte of Funaria hygrometrica during ontogenesis, Acta. Soc. Bot. Pol. 2: 207-215.

Krupa J., 1977, Photosynthetic activity of the leaves of mosses in relation to their anatomical structure, Acta. Soc. Bot. Pol. in press.

Lange O. L., Schulze E. D., Koch W., 1970, Experimentall-ökologische Untersuchungen an Flechten der Negev-Wüste. III. $\mathrm{CO}_{2}$ Gaswechsel und Wasserhaushalt von Krusten und Blattflechten am natürlichen standort Während der sommerlichen Trockenperiode, Flora 159: 525-538.

Lange O. L., Evenari M., 1971, Experimentall-ökologische Untersuchungen an Flechten der Negev-Wüste, Flora 160: 100-104.

Lee J. A., Stewart G. R., 1971, Desiccation injury in moses. I. Intraspecific differences in the effect of moisture stress on photosynthesis, New Phyttol. 70: $1061-1068$.

Plantefol M. S., 1927, Etude biologique de l'Hypnum triquetrum; realations et l'écologie d'un espèce végétable. Ann. Sci Nat. Ser. Bot. 9: 1-269.

Stalfelt M. G., 1937, Der Gesaustausch der Moose, Planta 27: 30-60.

Stalfelt M. G., 1960 Flechten und Moose, Handb. der Pflanzenphysiol. 5. t. II.: $364-375$.

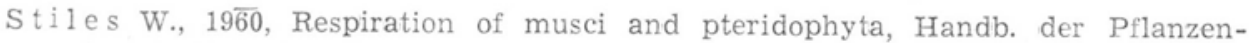
physiol. 12: 461-467.

Tallis J.H., 1959, Studies in the biology and ecology of Rhacomitrium lanuginosum. II. Growth, reproduction and physiology, Journ. of Ecology 47: 325-350.

Tallis J. H., 1964, Growth studies on Rhacomirium lanuginosum, The Bryologist, 67: $417-422$. 
Zurzycki J., Daykowska J., 1959, Gravimetric studies on pollen, Bull. de Acad. Pol. des Sci., 7: 11-16.

Zurzycki J., 1970, Some improvements of the microrespirometric technique, Acta Soc. Bot. Pol., 39: 497-507.

\author{
Author's address: \\ Doc. dr hab. Jan Krupa \\ Institute of Biology, \\ Higher Pedagogical School, \\ ul. Podbrzezie 3 \\ 31-054 Kraków, Poland
}

\title{
Zależność między natężeniem transpiracji a struktura anatomiczna liści mchów
}

Streszczenie

Stopień zróżnicowania anatomicznego liści mchów jak i różne warunki siedliskowe życia tych roślin były podstawą doboru następujących gatunków: Mnium punctatum, Catherinea undulata, Funaria hygrometrica, Polytrichum juniperinum, Polytrichum piliferum, Aloina rigida. Różna budowa anatomiczna odciętych liśc: mchów nie wpływa w zasadzie na ilość wyparowanej wody w ciągu 24 godz. okresu przetrzymywania ich w powietrzu o wilgotności względnej wynoszącej 85 i 95\%. Stwierdzone różnice w dynamice utraty wody z liści w warunkach wilgotności względnej powietrza $85 \%$ są raczej związane z własnościami i budową ściany komórkowej, chociaż mogą również wynikać z różnej oporności cytoplazmy na wysychanie. Proces fotosyntezy wykazuje znacznie większą wrażliwość na zmiany ilości wody w liściu niż oddychanie. Aktywność oddychania u większości badanych gatunków wyraźnie spada chociaż nie następuje całkowite jego zahamowanie po stosowanym okresie wysuszania. 